Sri Lanka J. Aquat. Sci. 15 (2010): 45-60

\title{
Influence of turbidity regime on larval settlement patterns of stony coral Pocillopora damicornis in Polhena reef, Sri Lanka
}

\section{P.B. TERNEY PRADEEP KUMARA}

Department of Oceanography and Marine Geology, Faculty of Fisheries and Marine Sciences \& Technology,University of Ruhuna,Matara, Sri Lanka.

E-mail: terney@fish.ruh.ac.lk

\begin{abstract}
Coral population structure is determined mainly by the larval settlement and recruitment pattern of sclerectenian corals. This pattern is mainly influenced by various environmental parameters such as temperature, $\mathrm{pH}$, salinity, depth, current velocity and direction, tidal variations and turbidity. Experiments reported here examine the impacts of turbidity on the spatio-temporal distribution patterns of larval settlement of Indo-Pacific coral, Pocillopora damicornis at Polhena reef of Southern Sri Lanka. The experiment was conducted in four sites. Depending on the topography and the characteristics of the reef substrate each site was further divided in to three locations as reef crest, mid reef flat and reef lagoon.

Terracotta tiles were attached to quantify larval settlement rates. Tiles were retrieved in monthly intervals and observed for $P$. damicornis larval settlements. Turbidity measurements were taken from the same locations. Larval settlement and turbidity showed a significant temporal $(\mathrm{P}<0.05)$ and spatial variation (MDS stress $<0.1$ ). The highest settlement rate and turbidity level were observed in May and March respectively. A significant relationship was observed between larval settlement pattern and sedimentation regime (RELATE test, $\rho=0.251, \mathrm{P}<0.05$ ).
\end{abstract}

\section{Introduction}

The presence of a healthy coral population is important for reef health, and also critically important for the ecosystem goods and services they provide to maritime tropical and subtropical nations (Moberg and Folke 1999). Many of them are important to local economies and subsistence in more than 181 countries that have coral reefs (Wilkinson 2004). However, Reefs are in serious decline worldwide (Gardner et al. 2003; Hughes et al. 2003; Pandolfi et al. 2003) an estimated $30 \%$ are already severely damaged, $11 \%$ of the original extent of coral reefs has already been lost (Wilkinson 2000) and close to $60 \%$ may be lost by 2030 (Wilkinson 2002). An estimated 58\% of reefs are classified as threatened (Bryant et al. 1998). Therefore, at present, there are no pristine reefs left (Pandolfi et al. 2003). The causes for coral decline are thought to include a combination of direct anthropogenic factors, such as overfishing, pollution, and sedimentation (Rogers 
and Beets 2001), as well as climate change (Hughes et al. 2003) and natural disturbances (Aronson and Precht 2001).

Tropical coral reefs are increasingly threatened by shifts in the world's climate, overfishing and declining water quality (Knowlton 2001; Wilkinson 2002; Hughes et al. 2003). They are particularly sensitive to increasing temperature and many other stressors making coral reef ecosystems especially vulnerable to global climate change (Donner et al. 2005). On a global scale, the most serious destruction of corals is due to bleaching (Hoegh-Guldberg 1999). In addition to eventually killing corals, bleaching affects coral populations by greatly reducing the reproductive capacity, reducing the growth rate, and increasing the susceptibility to secondary diseases (Fine 2001), which have been found increased in frequency, intensity, and geographic extent over the last few decades (Rosenberg and Benhaim 2002). In addition to that, rapid increase in atmospheric Carbon Dioxide concentrations $\left(\left[\mathrm{CO}_{2}\right]_{\mathrm{atm}}\right)$, by driving global warming and ocean acidification may be the final insult to coral ecosystems (Hoegh-Guldberg et al. 2007). As a result, almost all coral reefs in the world are in highly stressed and degraded condition.

Global climate change and associated events are highly linked with coastal pollution (Jones et al. 2004) and regional weather changes. The consequent changes in the physico-chemical environment are evidently the major reason for coral reef community susceptibility and ecosystem fragility (McClanahan 2002). Number of other environmental factors, such as increased seawater temperature, (Muscatine et al. 1991) increased irradiation (Gleason and Wellington 1993) and reduced salinity (Woesik et al. 1995) have been suggested to cause stressful conditions.

Suspended sediments are almost universally recognized as having inhibitory or negative effects on reef communities (McLaughlin 2003), and the related turbidity can affect the ecology and composition of reef communities (Stafford-smith 1993). Reduced light availability, which is the primary energy source for clear water corals (Anthony and Fabricius 2000) and increased energy demand for self cleaning activities therefore hamper other vital functions like feeding (Abdel-Salem and Porter 1989), growth and reproduction (Barnes and Lough 1999) and fecundity. Suspended sediment inhibits fertilization, larval survival and larval settlement (Gilmour 1999) and also physically abrades larvae, or may be detrimental to water quality. The presence of suspended material may lessen the water quality and increase concentrations of bacteria that would affect larval survival.

The spawning event of most scleractinian corals shows a seasonal and temporal variation with a well-defined lunar periodicity. For example, the spawning of the genus Pocillopora, varies from reef to reef and also from species to species (Fan et al. 2002). Harriott (1983) found out that the lunar periodicity of $P$. damicornis planula is a geographically variable phenomenon, and shows variation even within the same locality. The pattern may even differ between different morphs within the same location (Tanner 1995). For example, in Hawaii, one morph of $P$. damicornis displays peak planula release between first quarter and full moon, while another peak around three quarter moon (Richmond and Jokiel 1984). This phenomenon has been widely studied throughout the Indo-pacific (northern Great Barrier Reef: Marshall and Stephenson 1933; Harriott 1983; Palau: Hawaii: 
Harrigan 1972; Enewetak, Red Sea: Richmond and Jokiel 1984; Western Australia: Stoddart and Black 1985).

There are number of factors affecting the settlement pattern of coral larvae. Pre-settlement factors, such as orientation of settlement for sedimentation and light levels may play an important role in determining reef-scale distribution patterns (Babcock and Mundy 1996). Specially, the first months of development are influenced by sediment and filamentous turf algae (Babcock and Mundy 1996). Major post-settlement factors are predation and competition. They could rapidly alter the abundance and distribution of coral spat (Fitzhardinge and Bailey-Brock 1989).

Coral larval settlement and recruitment have been previously shown to respond to various forms of stress factors and levels. Most of the studies conducted to date have focused on testing under different environmental conditions. They are, oil pollution (Rinkevich and Loya 1979; Negri and Heyward 2000), sediments (Hodgson 1990), temperature (Edmunds et al. 2001; Bassin and Sammarco 2003; Brooke and Young2005; Baird et al. 2006) and bleaching (Szmant and Gassman 1990), pesticides or heavy metals (Reichelt-Brushett and Harrison 2000; Negri and Heyward 2001; Negri et al. 2002), salinity changes (Vermeij et al. 2006; Richmond 1994), intraspecific competition (Rinkevich and Loya 1985), ultraviolet radiation (Welington and Fitt 2003), estimating median survival time (i.e., the point at which $50 \%$ of the cohort have died) (Harii et al. 2002; Nishikawa and Sakai 2005; Nozawa and Harrison 2005) and the physical damage (Van Vegel and Bak 1994). However, the knowledge about the effect of turbidity regime under natural conditions on the settlement patterns of scleractinian coral is lacking.

It is evident that differences exist among scleractinian corals with respect to survival and growth after settlement. This could be related to their life history strategies, or to the other external environmental factors. Turbidity is one of the important environmental factors affect on the settlement and recruitment of coral larvae. The main hypothesis we tested in this study was that the settlement patterns are independent to different the turbidity levels. During this study, we tracked association between the larval settlement pattern of $P$. damicornis and the variation in turbidity levels in Polhena reef of Southern Sri Lanka.

\section{Materials and methods}

\section{Study area}

The experiment was conducted in Polhena reef $\left(05^{\circ} 56.176^{\prime} \mathrm{N}, 80^{\circ}\right.$ $31.591^{\prime} \mathrm{E}$ ) of southern coast of Sri Lanka (Fig 1). The reef is fringing type, stretching east-west paralleled to the coast. The eastern end of the reef is exposed to excess nutrient and sediment influx from the nearby Nilwala River which drains to the sea at $1 \mathrm{~km}$ distance from the reef. Southern coastal area receives heavy rains during May to August period, accompanied by heavy rains and rough sea conditions. September-November period is the inter-monsoon, the wind direction is often variable and frequently accompanied by rains. Between December and April, winds are generally weak, the weather is dry and the sea is calm. 


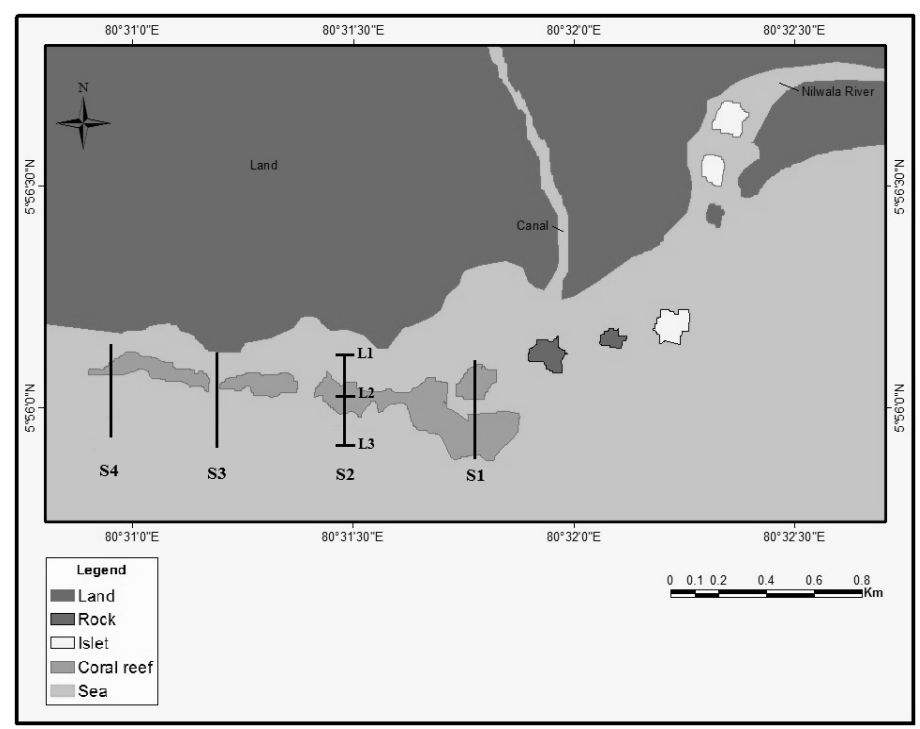

Figure 1. Map of Polhena reef indicating sampling sites and locations

\section{Sites and locations}

Four sites were selected along Polhena reef representing the whole stretch of the reef. The site 1 located near to the Nilwala River outfall with strong waves passing along the site. The site 2 is westward to the site 1 and site 3 is further westward. This site showed the highest human activities with excess reef walking and high fishing pressure. Site 4 is the most westward with relatively high water clarity. Each site was divided into three locations according to the topography of the reef namely reef crest, reef top and reef lagoon (Table 1). Reef crest was the most seaward location while reef lagoon was the most landward location. Reef top was situated between reef crest and reef lagoon.

\section{Candidate species}

The species selected for the study, $P$. damicornis is abundant in the area and is considered as the most successful colonizer during the recovery of disturbed coral reefs (Wallace 1985). This species is the best studied scleractinian species with respect to patterns of planulae release and settlement preferences (Harriott 1983). It shows great deal of morphological differences according to the habitat differences and also the number of planulae released and gonad development varied considerably among colonies (Harriott 1983). The species displays a marked seasonal variation in reproductive output, with nearly all reproductive activity occurring over the warm summer months (Tanner 1996).

\section{Larval settlement patterns}

Settlement plates of suitable materials could provide reliable measures of benthic life-history traits (Mundy, 2000). In this light, we used terracotta tiles as artificial coral larval settlement surfaces for $P$. damicornis. At each location, ten tiles were directly attached to the reef using cable ties exposing the non-glazed side. 
Tiles were retrieved in each three months interval, bleached, dried and all $P$. damicornis coral spats were counted.

\section{Environmental parameters}

Turbidity was measured in nephelometric turbidity units (NTU) using a turbidity meter (HACH 2100P digital portable turbidity meter). At each location, measurements were taken in situ at monthly intervals. Care was taken to measure the turbidity at the same depth and the time $(9-10 \mathrm{hrs}$.) of the day during data collection.

Table 1. Categorization of substratum zones (adapted from Lewis 1999)

\section{Reef Location (Zone) Characteristics}

Location I

(Reef crest )

Location II

(Mid reef flat)

Location III

(Reef lagoon)
Over $80 \%$ of dead and hard coral cover. Sturdy $P$. verrucosa species. Occasional Sargassum sp. patches. No rubble. The crest structure is broken up by large coral and rocky outcrops. High energy water currents. Depth range up to $2 \mathrm{~m}$.

Benthos dominated by coral rubble. Coralline alga Halimeda sp. grown on the top of a flat coral rubble layer. Live coral cover is less than $15 \%$. Live corals are mainly encrusting or short branching type. Depth range up to $0.5 \mathrm{~m}$.

More than $80 \%$ silt and sand cover with occasional sea grass patches. Contains some boulder type dead coral patches. Rubble cover increases towards the outer edge of the lagoon. Depth range up to $1 \mathrm{~m}$.

\section{Statistical analysis}

Temporal distribution pattern of environmental data and coral settlement data were visually analyzed using Microsoft office Excel package. Temporal variation between sites and locations was assessed using ANOVA (repeated measures) method followed by Tukey's pair wise comparison test. SPSS (Statistical Package for Social Sciences, version 15.0) was used in parametric tests. Primer (Plymouth Routines In Multivariate Ecological Research) v6 was used for non parametric tests. Recruitment data and turbidity measurements were first analyzed using Multi Dimensional Scaling (MDS) with no data transformation in Bray Curtis similarity matrix. MDS ordinations for $P$. damicornis settlement pattern and turbidity variation were compared using RELATE test to assess the relationship between them. The null hypothesis tested was that, there is no relationship between the settlement pattern and turbidity variation, hence $\rho$ will be approximately zero. 


\section{Results}

Variation in P. damicornis settlements

The highest coral larval settlement rate was observed in May and the lowest in February (Figure 2). Temporal variations of coral larval settlement pattern indicated that there was a significant difference in settlement peaks during the year $\left(\mathrm{F}_{3,72}=140.495, \mathrm{P}<0.000\right)$. Coral settlement pattern varied significantly between sites $\left(\mathrm{F}_{3,24}=8.135, \mathrm{P}<0.001\right)$ and also between locations $\left(\mathrm{F}_{2,24}=58.347, \mathrm{P}<0.000\right)$. However no site and location interaction was observed.

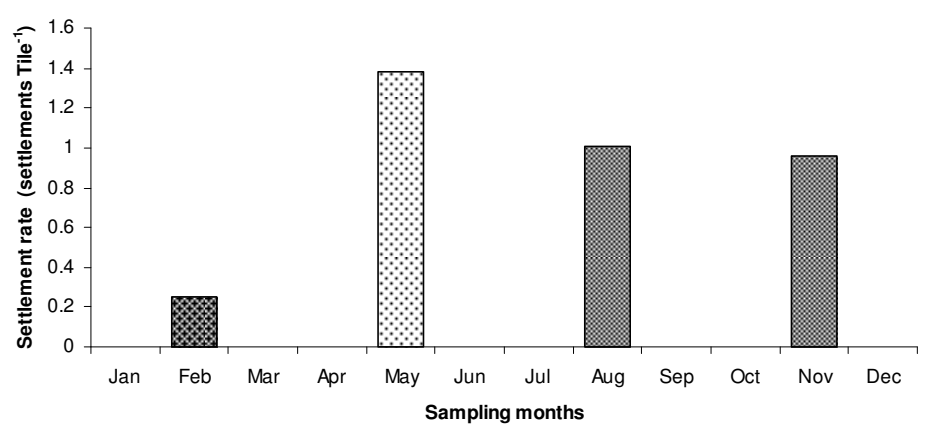

Figure 2. Coral larval settlement pattern at the sampling months.

\section{Variation in turbidity}

Turbidity levels changed significantly with the time $\left(\mathrm{F}_{11,264}=77.147\right.$, $\mathrm{P}<0.000$,) (Figure 3). Highest levels were observed in March (4.44 \pm 1.10 SD NTU), the first part of the year, and the values decreased towards the end of the year. The lowest values were observed in October (1.68 \pm 0.11 SD NTU). Turbidity values showed significant variations between sites $\left(\mathrm{F}_{3,24}=12.523, \mathrm{P}<0.000\right)$ and between locations $\left(\mathrm{F}_{2,24}=116.870, \mathrm{P}<0.000\right)$. There was no site and location interaction observed.

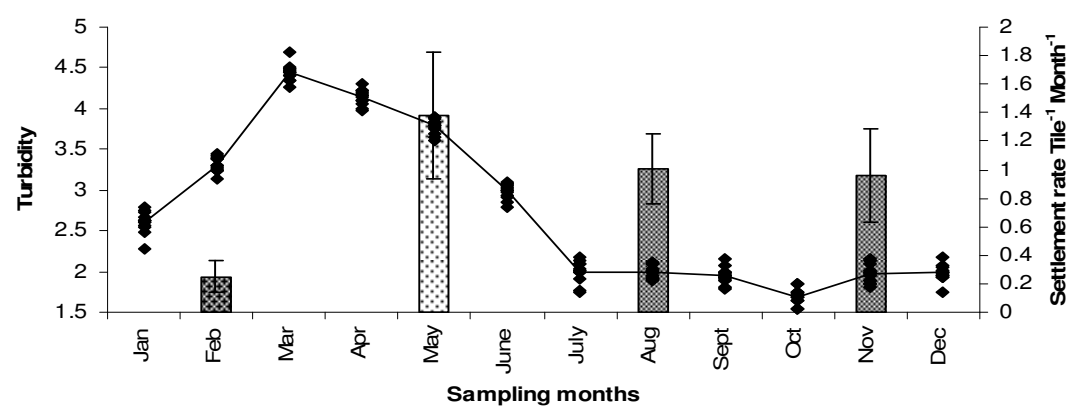

Figure 3. Bar chart indicates the settlement rates at each tile collection (number of settlements, Tile ${ }^{-1}$, Month ${ }^{-1} \pm \mathrm{SD}$ ). Different patterns on the bar graph indicate significantly different sub groups $(\mathrm{P}<0.05$; Tukey HSD). The mean values of each month are linked to show the temporal variation of the Turbidity regime. 


\section{Relationship between settlement pattern and turbidity regime}

MDS ordinations for larval settlement rates and turbidity levels were almost identical (Figure 4). Settlement rates showed a grouping between locations (L1, L2 and L3) (Figure. 4A). Turbidity variation showed the similar pattern (Figure B). In both MDS plots, the Kruskal stress value $<0.1$ indicating the grouping between locations to be significant.

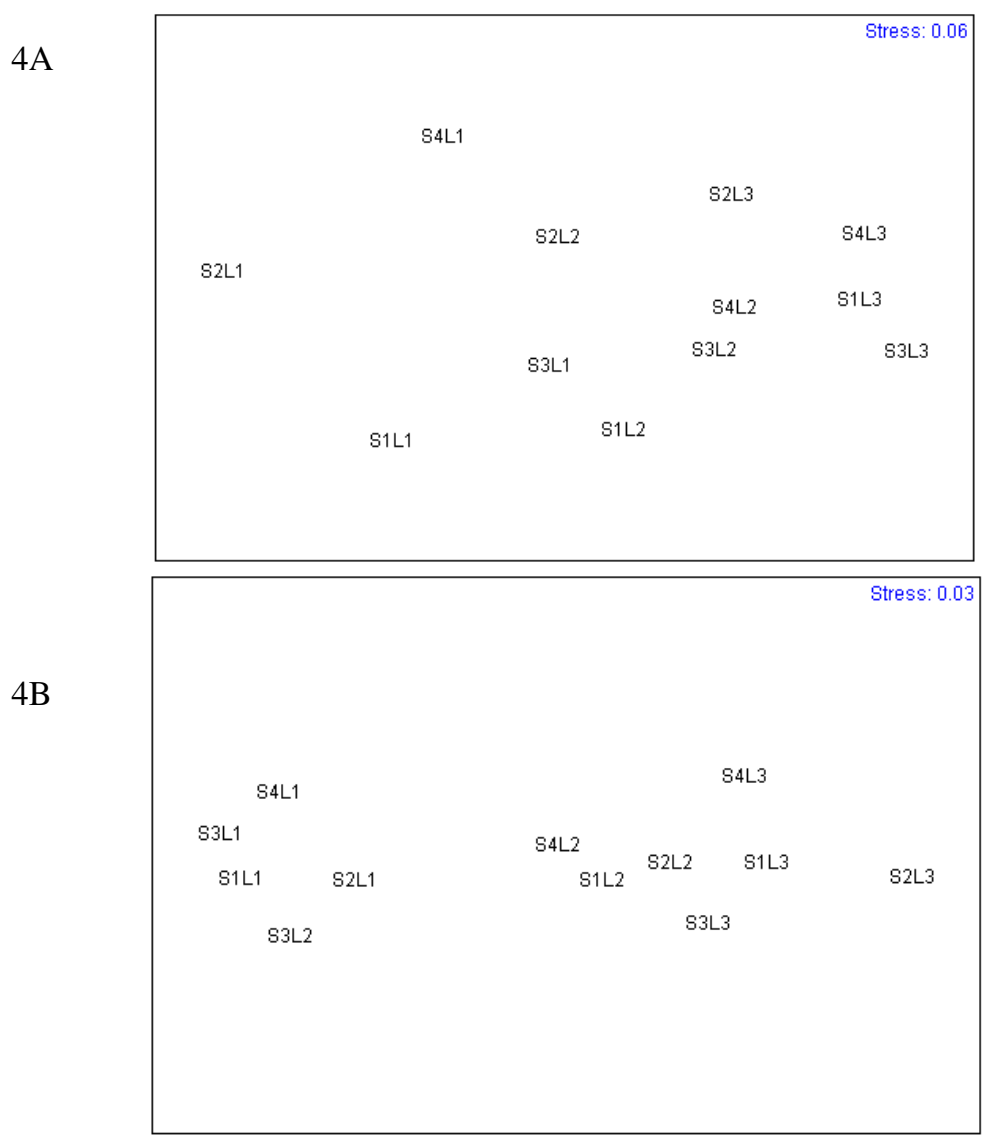

Figure 4. Two dimensional MDS (A; Settlements, B; Turbidity) with no data transformation with Bray-Curtis similarities showing the spatial distribution of sites (S) and locations (L) at Polhena reef (Kruskal stress < 0.1).

The RELATE results emphasize the relationship between two independent variables. Out of 999 permutations, only 30 permuted statistics were greater than $\rho$. The sample statistics $(\rho)$ obtained in RELATE test for settlement and turbidity was 0.251 and the significant level of the sample statistics was $0.031(3.1 \%)$, which is less than 0.05 probability level (Figure 5). This result rejects the null hypotheses that there is no relationship between two similarity matrices obtained from coral larval settlement data and turbidity variation data, and hence accepts the alternative hypothesis that there is a significant relationship between these two parameters. 


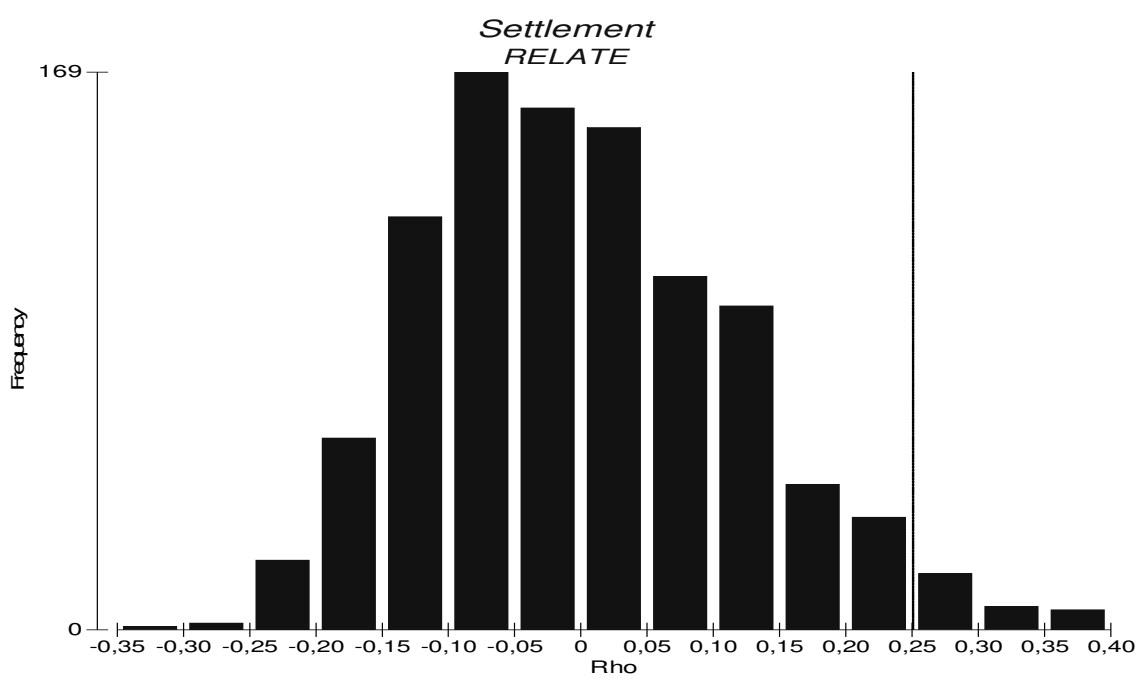

Figure 5. Histogram shows that the observed $\rho$ is 0.251 and out of 999 permuted statistics only 30 values are greater than or equal to $\rho$.

\section{Discussion}

P. damicornis settlement pattern showed a significant variation with the time, sites and locations (Nozawa and Harrison 2002; Miller and Mundy 2003; Nishikawa et al. 2003; Harrison 2006). The highest amount of coral settlement rate was observed in May and the lowest in February tile collections. The main reason for this is probably the coral spawning during the March - May period. Glassom et al. (2004) observed the same recruit pattern during spring to mid-summer (March and June) at Eilat, Red Sea. Settlement peaks observed in August and November are secondary peaks, most likely from secondary spawning events occurred in June August and September - November periods respectively. This is especially true to corals that are known to have wide temporal variation in their levels of reproduction (Hughes et al. 2000). However, the August and November peaks might also be a result of the initial spawning occurred in March - May period. The most likely reason is that some larvae are spending a considerable time in the water column in a planktonic state. For example, Richmond (1987) and Harii et al. (2002) showed that, for brooding species such as $P$. damicornis, the competency period of planula exceeded 100 days in the Marshall Islands and the Ryukyu Archipelago. Harii et al. (2002) also showed that the competency period of Heliopora coerulea was 30 days in the Ryukyu archipelago. In addition to that, secondary settlement peaks can be resulted by delayed settlements, caused by low temperature and consequent slow development (Pearse et al. 1991).

Turbidity is an aggregate property of water. It, in open water may be caused by growth of plankton and suspended sediments including silt, mud, chemical precipitation and bacteria. Human activities that disturb lands such as deforestation, farming, urbanization, and construction activities can lead to high sediment levels in water bodies due to rain runoff. 
Each year turbidity values were low from July to January. The maximum range was observed in the March - May period. These values were not consistent with the monsoonal pattern in the area. The South - West monsoon period starts in May and lasts until August. Inter monsoon period lasts from September to November. However during this rainy season, the observed turbidity levels remained low.

The most likely explanation for this turbidity regime is the mixing of suspended material rich river discharge, with oceanic currents and the consequent changes of oceanic currents according the weather pattern. Experimental evidence suggests that turbidity concentrations are detectable over a much greater area in major river plumes that directly enter to the oceanic environment, (Cresswell and Tiledesley 2000). However, this phenomenon is well known among local fishermen. They have observed for decades, that the surface layer of the reef lagoon is covered with turbid brackish water during particular periods of the year even without the monsoon rain. During other parts of the year the reef lagoon is filled withclear marine water. Ogston et al. (2004), Storlazzi et al. (2004) and Presto et al. (2006) observed that re-suspension of reef sediments is linked to tidal variation and wind pattern, and is greatest during high tide because offshore wave energy more effectively propagate over the reef crest. However, the oceanographic sediment transport mechanism in shallow water reef environment is largely unexplored (Hoitikn 2003), particularly in Sri Lankan context. Since these mechanisms determine the regional dispersion of terrigenous sediment and its availability in the inshore waters, the understanding of such mechanisms are essential.

I found that the spatio-temporal variation of $P$. damicornis settlement pattern and turbidity regime was significantly related at Polhena reef lagoon. Turbidity is an important environmental parameter in reef environment that affects negatively on the physiology and the reproductive pattern of scleractinian corals. Reduced fecundity (Kojis and Quinn 1984), reduced gamete formation and larval development and settlement, reduced recruit and juvenile density and diversity, increased juvenile mortality (Tomasick and Sander 1987; Tomasick 1991; Hunte and Wittenberg 1992; Wittenberg and Hunte 1992), low coral recruitment (Mortn 1994; Hodgson and Yau 1997) and inhibition of coral larval settlement (Hodgson 1990; Hodgson and Walton Smith 1993) are major impacts of higher sediment loads in marine environments.

Corals and coral reefs can grow and survive in turbid water (Anthony 2000). However, turbid water corals and coral reefs experience more stressful conditions. It has been demonstrated that increased turbidity and siltation in the coastal zone are potential causes of coral reef degradation (James et al. 2002). Some of the major impacts of reef destructions are disappearance of sensitive species, declining of biodiversity (Hodgson, 1990; Hodgson and Walton Smith 1993) and few zooxanthellate octocorals and disappearance of giant clams (Tridacna spp.) (Mortn 1994; Hodgson and Yau 1997). Further, increased turbidity cause stressed conditions to corals and other marine invertebrates. e.g., high turbidity (28-30 NTU) increased mucus production (Telesnicki and Goldberg 1995). High turbidity levels can block light from reaching lower depths of water bodies, which can inhibit coral growth, inhibit submerged aquatic plants and trap sediment by increased algal 
growth. Walker and Ormond 1982 observed fourfold increase in mortality and inhibition of calcification in Stylophora pistillata in high turbid waters.

The present study provides a broad insight on the effect of turbidity on the settling pattern of coral spats, but simultaneously stresses the need for additional research for a better understanding. More specific investigations are required to study the effect of different levels of turbidity, multiple environmental parameters, coastal mixing of river runoff and effects of ocean currents in coastal waters on different coral species, and indigenous knowledge on coastal current patterns.

\section{Acknowledgements}

I would like to especially thank Dr. Roland Engkvist and Patrik Dinnetz for their guidance in statistical data handling. This work was supported by grants from the SIDA/SAREC Marine Science Program of the Department of Oceanography and Marine Geology of the Faculty of Fisheries and Marine Sciences \& Technology, University of Ruhuna, Matara, Sri Lanka and Asian Development Bank (ADB) Personnel Development Program of the Ministry of Science and Technology.

\section{References}

Abdel-Salem, H.A. \& J.W. Porter 1989.

Physiological effects of sediment rejection on photosynthesis and respiration in three Caribbean reef animals. Proceeding of the $6^{\text {th }}$ international coral reef symposium, vol.2 pp. 285-292.

Anthony, K.R.N. 2000.

Enhanced particle feeding capacity of corals on turbid reefs (Great Barrier Reef, Australia). Coral Reefs 19: 59-67.

Anthony, K.R.N. \& K.E. Fabricius 2000.

Shifting role of heterotrophy and autotrophy in coral energetic under varying turbidity. Journal of Experimental Marine Biology and Ecology 252: 221-253.

Aronson, R.B. \& W.F. Precht 2001.

Evolutionary paleoecology of Caribbean coral reefs. (D.J. Bottjer eds), pp 171-233. Evolutionary paleoecology: the ecological context of macro evolutionary change. Columbia University Press, New York, USA.

Atoda, K. 1947.

The larval and post larval development of some coral building corals. I.

Pocillapora damicornis (Dana). Science Report Tohoku ( $4^{\text {th }}$ Ser) 18: 24-47.

Babcock, R. \& C. Mundy 1996.

Coral recruitment: consequences of settlement choice for early growth and survivorship in two scleractinian, Journal of Experimental Biology and Ecology 206: 179-201. 
Baird, A.H., J.P. Gilmour, T.M. Kamiki, M. Nonaka, M.S. Pratchett, H.H. Yamamoto, \& H.Yamasaki 2006.

Temperature tolerance of symbiotic and non symbiotic coral larvae. Proc 10th International Coral Reef Symposium 1: 38-42.

Barnes, D.J. \& J.M. Lough 1999.

Porites growth characteristics in a changed environment: Misima Island, Papua New Guinea. Coral Reefs 18: 213-218.

Bassim, K.M. \& P.W. Sammarco 2003.

Effects of temperature and ammonium on larval development and survivorship in a sclerectinian coral (Diploria strigosa). Marine Biology 142: 241-252.

Brooke, S. \& C.M. Young 2005.

Embryogenesis and larval biology of the ahermatypic scleractinia Oculina varicosa. Marine Biology 146: 665-675.

Bryant, D., L. Burke, J.M. McManus \& M. Spalding 1998.

Reefs at risk. A map based indicator of threats to the world's coral reefs. World Resources Institute, Washington, D.C., USA

Cresswell, G.R. \& P.C. Tiledesley 2000.

Detecting tropical river plumes and island wakes with RADARSAT. Canadian Journal of Remote sensing 26(4), 267-272.

Donner, S.D., W.J. Skirving \& C.M. Little 2005.

Global assessment of coral bleaching and required rates of adaptation under climate change. Global Change Biology 11: 2251-2265.

Edmunds, P.J., R.D. Gates \& D.F. Gleason 2001.

The biology of larvae from the reef coral Porites astreoides, and their response to temperature disturbances. Marine Biology 139: 981-989.

Fan, T.Y., J.J. Li, S.X. Le, \& L.S. Fang 2002.

Lunar periodicity of larval release by pocilloporid corals in Southern Thaiwan. Zoological studies 41(3): 288-294.

Fine, M., H. Zibrowius, \& Y. Loya 2001.

Oculina patagonica: a non-lessepsian scleractinian coral invading the Mediterranean Sea. Marine Biology 138: 1195-1203.

Fitzhardinge, R.C. \& J.H. Bailey-Brock 1989.

The colonization of artificial reef materials by coral and other sessile organisms. Bulletin of Marine Science 44: 567-579.

Gardner, T.A., I.M. Cote, J.A. Gill, A. Grant \& A.R. Watkinson 2003.

Long term region-wide declines in Caribbean corals. Science 301: 958-960.

Gilmour, J. 1999.

Experimental investigation into the effects of suspended sediment on fertilization, larval survival and settlement in a scleractinian coral. Marine Biology 135: 451-462.

Glasson, D., D. Zakai \& N.E. Chadwick-Furman 2004.

Coral recruitment: a spatio-temporal analysis along the coastline of Eilat, northern Red Sea. Marine Biology 144: 641-651.

Gleason, D.F. \& G.M. Wellington 1993.

Ultraviolet radiation and coral bleaching. Nature 365: 836-838. 
Harii, S., H. Kayanne, H. Takigawa, T. Hayashibara \& M. Yamamoto 2002.

Larval survivorship, competency periods and settlements of two brooding corals, Heliopora coerulea and Pocillopora damicornis. Marine Biology 141:39-46.

Harrigan, J.F. 1972.

The planula larva of Pocillopora damicornis: lunar periodicity of swarming and substrate selection behavior. $\mathrm{PhD}$ thesis, University of Hawaii.

Harrison, P.L. 2006.

Settlement competency period and dispersal of scleractinian reef coral larvae. Proceedings of the $10^{\text {th }}$ International Coral Reef Symposium, Okinawa, Japan. June 28-July 2, 2004. 78-82 pp.

Harriott, V.J. 1983.

Reproductive seasonality, settlement and post settlement mortality of

Pocillpora damicornis (Linnaeus), at Lizard Island, Great Barrier Reef.

Coral Reefs 2: 151-157.

Hodgson, G. 1990.

Sediment and the settlement of larvae of the reef coral Pocillopora damicornis. Coral Reefs 9: 41-43.

Hodgson, G. \& F.G. Walton Smith 1993.

Sedimentation damage to reef corals, Global aspects of coral reefs: Health, hazards and history. University of Miami, pp. 25-20.

Hodgson, G. \& E.M. Yau 1997.

Physical \& biological control coral communities in Hong Kong. In: Lessions, H.A. Macintyre, I.G. (eds.), Proceedings of the $8^{\text {th }}$ International Coral Reef Symposium, Smithsonian Institute Press, Balboa, Panama, pp. 459-461.

Hoegh-Guldberg, O. 1999.

Climate changes, coral bleaching and the future of the worlds coral reefs.

Marine Freshwater Research 50: 839-866.

Hoegh-Guldberg, O., P.J. Mumby, A.J. Hooten, R.S. Steneck, P. Greenfield, E. Gomez, C.D. Harvell, P.F. Sale, A.J. Edwards, K. Caldeire N. Knowlton, C.M. Eakin, R. Iglesias-Prieto, N. Muthiga, R.H. Bradbury, A. Dubi, \& M.E. Hatziolos 2007.

Coral reef under climate change and ocean acidification. Science 318: 1737-1742

Hoitink, A.J.F. \& P. Hoekstra 2003.

Hydrodynamic control of the supply of reworked terrigenous sediment to coral reefs in the Bay of Banten (NW jaw, Indonesia). Estuarine coastal and Shelf Science 58: 743-755

Hughes, T.P., A.H. Baird, D.R. Bellwood, M. Card, S.R. Connolly, C. Folke, R. Grosberg, O. Hoegh-Guldberg, J.B.C. Jackson, J. Kleypas, J.M. Lough, P. Marshall, M. Nystrom, S.R. Palumbi, J.M. Pandolfi, B. Rosen \& J. Roughgarden 2003.

Climate change, human impacts, and the resilience of coral reefs. Science 301: 929-933. 
Hughes, T.P., A.H. Baird, E.A. Dinsdale, N.A. Moltschaniwskyj, M.S. Prattchett, J.E. Tanner \& B.L. Willis 2000.

Supply-side ecology works both ways: the link between benthic adult, fecundity and larval recruits. Ecology 81: 2241- 2249.

Hunte, W. \& M. Wittenberg 1992.

Effects of eutrophication and sedimentation on juvenile corals. 2 . Settlement. Marine Biology 114: 625-631.

James, M., C. Crabbe \& J.D. Smith 2001.

Comparison of two reef sites in the Wakatobi Marine National Park (SE

Sulawesi, Indonesia) using digital image analysis. Coral Reefs 21: 242-244.

Jones, C.G., J.H. Lowton \& M. Shachak 1994.

Organisms as ecosystem engineers. Oikos 69: 373-386.

Jones, G.P., M.I. McCormick, M. Sriniwasan \& J.V. Eagle 2004.

Coral decline threatens fish biodiversity in marine reserves Proceedings of the National Academy of Science, USA (PNAS) 101 8251-8253.

Kojis, B.L. \& N.J. Quinn,1984.

Seasonal and depth variation in fecundity of Acropora palifera at two reefs of Papua New Guinea. Coral Reefs 3: 165-172.

Knowlton, N. 2001.

The future of coral reefs. Proceedings of the National Academy of Science, USA (PNAS) 98: 5419-5425.

Marshall, S.M. \& T.A. Stephenson 1933.

The breeding of the reef animals.1. The corals. Great Barrier Reef Expedition 1928-29, Science Report 3: 219-245.

McClanahan, T.R. 2002.

The near future of coral reefs. Environnemental Conservation 29: 460-483.

McLaughlin, C.J., C.A. Smith, R.W. Buddemeier, J.D. Bartley \& B.A. Maxwell 2003.

Rivers, runoff and reefs. Global and Planetary Change 39: 191-199.

Miller, K. \& C.N. Mundy 2003.

Rapid settlement in broadcast spawning corals: implication for larval dispersal. Coral Reef 22: 99-106.

Moberg, F. \& C. Folke 1999.

Ecological goods and services of coral ecosystems. Ecological Economics 29: 215-233.

Morton, B. 1994.

Hong Kong's coral communities: status, threats and management plan. Marine Pollution Bulletin 29: 74-83

Mundy, C.N. 2000.

An appraisal of methods used in coral recruitment studies. Coral Reef 19: 24-131.

Muscatine, L., D. Grossman \& J. Doino 1991.

Release of symbiotic algae by tropical sea anemones and corals after cold shock. Marine Ecology Progress Series 77: 233-243. 
Negri, A.P. \& A.J. Heyward 2000.

Inhibition of fertilization and larval metamrphosis of the coral Acropora millepora (Ehrenberg 1834) by petroleum productions. Marine Pollution Bulletin 41: 420-427.

Negri, A.P. \& A.J. Heyward 2001.

Inhibition of coral fertilization and larval metamorphosis by Tributyl Tin and Copper. Marine Environmental Research 51: 17-27.

Negri, A.P., L.D. Smith, N.S. Webster \& A.J. Heyward 2002.

Understanding ship-grounding impacts on a coral reef: potential effects of anti-foulant paint contamination on coral recruitment. Marine Pollution Bulletin 44: 111-117.

Nishikawa, A. \& K. Sakai 2005.

Settlement-competecy period of planulae and genetic differentiation of the sclereactinian coral Acropora digitifera Zoological Science 22: 391-399.

Nishikawa, A., M. Katoh \& K. Sakai 2003.

Larval settlement rates and gene flow of broadcast-spawning (Acropora tenuis) and planula -brooding (Stylophora pistillata)corals, Marine Ecology Progress Series 256: 87-97.

Nozawa, Y. \& P.L. Harrison 2005.

Temporal settlement patterns of larvae of the broadcast spawning reef coral Favites chinensis and the broadcast spawning and brooding reef coral Goniastrea aspera from Okinawa, Japan. Coral Reefs 24: 274-282.

Ogston, A.S., C.D. Storlazzi, M.E. Field \& M.K. Presto 2004.

Current \& suspended sediment transport on a shallow reef flat: South central Molokai, Hawaii, Coral Reefs 23(4), 559-569.

Pandolfi, J.M., R.H. Bradbury, E. Sala, T.P. Hughes, K.A. Jorndal, R.G. Cooke, D. McArdle, L. McClenachan, M.J.H. Newman, G. Paredes, R.R. Warner \& J.B.C. Jackson 2003.

Global trajectories of the long term decline of coral reef ecosystems. Science 301: 955-958.

Pearse, J.S., J.B. McClintock \& I. Bosch 1991.

Reproduction of the Antarctic benthic marine invertebrates: Tempos, modes, and timing. American Zoologist 31: 65-80.

Presto, M.K., A.S. Ogston, C.D. Storlazzi \& M.E. Field 2006.

Seasonal and spatial controls on terrigenous sediment dispersal on a shallow fringing reef flat, Mololai, Hawaii. Estuarine Coastal and Shelf Science 67: 67-81.

Reichelt-Brushett, A.J. \& P.L. Harrison 2000.

The effect of copper on the settlement success of larvae from the scleractinian coral Acropora tenuis. Marine Pollution Bulletin 41: 385-391.

Richmond, R. 1994.

Effects of coastal runoff on coral reproduction. In Ginsburg R.N. (Ed.), Proceedings of the Colloquium on Global Aspects of Coral Reefs: Health, Hazards and History, 1993. University of Miami, Miami, pp. 360-364. 
Richmond, R.H. 1987.

Energetic relationships and biogeographical differences among fecundity, growth and reproduction in the reef coral Pocillapora damicornis. Bulletin of Marine Science 41: 594-604.

Richmond, R.H. \& P.L. Jokiel 1984.

Lunar periodicity in larval release in the reef coral Pocillapora damicornis at Enewetak and Hawaii. Bulletin of Marine Science 34: 280-287.

Rinkevich, B. \& L. Loya 1985.

Intraspecific competition in a reef coral: effects on growth and reproduction. Oecologia 66: 100-105.

Rinkevich. B. \& L. Loya 1979.

Laboratory experiments on the effects of crude oil on the Red Sea coral Stylophora pistillata. Marine Pollution Bulletin 10: 328-330.

Rogers, C.S. \& J. Beets 2001.

Degradation of marine ecosystems and decline of fishery resources in marine protected areas in the US Vergin Islands. Environmental Conservation 24: 312-322.

Rosenberg, E. \& Y. Ben-Haim 2002.

Microbial diseases of corals and global warming. Environmental Microbiology 4:318-326.

Stafford-Smith, M. G. 1993.

Sediment-rejection efficiency of 22 species of Australian scleractinian corals. Marine Biology 115:229-243.

Stoddart, J.A. \& R. Black 1985.

Cycle of gametogenesis and planulation in the coral, Pocillapora damicornis. Marine Ecology Progress Series 23: 153-164.

Storlazzi,C.D., A.S. Ogston, M.H. Bothner, M.E. Field \& M.K. Presto 2004.

Wave and tidally driven flow and sediment flux across a fringing coral reef:

Southern Molokai, Hawaii. Continental Shelf Research 24: 1397-149.

Szmant, A.M. \& N.J. Gassman 1990.

The effects of prolonged bleaching on the tissue biomass and reproduction of the reef coral Montastrea annularis. Coral Reefs 8: 217-224.

Tanner, J.E. 1996.

Seasonality and lunar periodicity in the reproduction of pocilloporid corals.

Coral Reef 11: 131-134.

Telesnicki, G.J. \& W.M. Goldberg 1995.

Effects of turbidity on the photosynthesis and respiration of two south Florida reef coral species. Bulletin of Marine Science 57: 527-539.

Tomasick, T. 1991.

Settlement patterns of Caribbean scleractinian corals on artificial substrata along a eutrophication gradient, Barbados, West Indies. Marine Ecology Progress Series 77: 261-269.

Tomasick, T. \& F. Sander 1987.

Effects of eutrophication on reef building corals. 3. Reproduction of the reef-building coral Porites porites. Marine Biology 94: 77-94. 
VanVegel, M.J.L. \& P.P.M. Bak 1994.

Reproductive characteristics of teh polymorphic Caribbean reef building coral Montastrea annularis. III. Reproduction in damaged and regenerating colonies. Marine Ecology Progress Series 109: 229-233.

Vermeij, M.J.A., Fogarty, N.D. \& M.W. Miller 2006.

Pelagic conditions after larval behavior, survival and settlement patterns in the Caribbean coral Montastrea faveolata. Marine Ecology Progress Series 310: 119-128.

Walker, D.I. \& R.F.G. Ormand 1982.

Coral death from sewage and phosphate pollution at Aqaba, Red Sea. Marine Pollution Bulletin 13: 21-25.

Wallace, C.C. 1985.

Seasonal peaks and annual fluctuations in recruitment of juvenile scleractinian corals. Marine Ecology Progress Series 21: 289-298.

Wellington, G.M. \& W.K. Fitt 2003.

Influence of UV radiation on the survival of larval from broadcastspawning reef coral. Marine Biology 143: 1185-1192.

Wilkinson, C.R. 2000.

GCRMN Status of the Coral Reefs of the world: 2000. Australian Institute of Marine Science, Townsville, Queensland.

Wilkinson, C.R. 2002.

GCRMN Status of the Coral Reefs of the world: 2002. Australian Institute of Marine Science, Townsville, Queensland.

Wilkinson, C.R. 2004.

GCRMN Status of the Coral Reefs of the world: 2004. Australian Institute of Marine Science, Townsville, Queensland.

Wittenberg, M. \& W. Hunte 1992.

Effects of eutrophication and sedimentation on juvenile corals. 1. Abundance, mortality and community structure. Marine Biology 116: 131138.

Woesik, V.R., De Vantier, L.M. \& J.S. Glazebrook 1995.

Effects of the cyclone joy on near shore coral communities of the Great Barrier Reef. Marine Ecology Progress Series 128: 261-270. 